\title{
Effects of Pituitary Adenylate Cyclase-Activating Polypeptide (PACAP) 27 and PACAP 38 on the Release of Luteinizing Hormone (LH) from Cultured Bovine Anterior Pituitary Cells
}

\author{
Shinichiro KOYAMA, Tsutomu HASHIZUME, \\ Shinichi OHASHI ${ }^{1)}$ and Shigeto KANEMATSU \\ Laboratory of Animal Reproduction, Faculty of \\ Agriculture, Iwate University, Morioka, Iwate 020, and \\ 1)National Institute of Bioscience and Human \\ Technology, Tsukuba, Ibaraki 305, Japan
}

\begin{abstract}
The effect of pituitary adenylate cyclase-activating polypeptide (PACAP) on the release of luteinizing hormone ( $\mathrm{LH})$ from cultured bovine anterior pituitary cells was determined and compared with that of luteinizing hormone-releasing hormone (LHRH). PACAP 27 significantly increased the release of bovine $\mathrm{LH}$ at a dose as low as $10^{-14} \mathrm{M}$. PACAP 38 also significantly increased the release of $\mathrm{LH}$ and the minimal effective dose was $10^{-12} \mathrm{M}$. Maximal $\mathrm{LH}$ release induced by PACAP $27\left(10^{-7} \mathrm{M}\right)$ and PACAP $38\left(10^{-7} \mathrm{M}\right)$ were $40.5 \%$ and $71.6 \%$, respectively of control levels. LHRH significantly increased the release of $\mathrm{LH}$ at a dose as low as $10^{-14} \mathrm{M}$. The increase in LH reached a maximum level which was 3-fold above the basal level at the highest concentration of LHRH tested $\left(10^{-7} \mathrm{M}, \mathrm{P}<0.001\right)$. LH release induced by PACAP 27, PACAP 38, and LHRH was in a dose-dependent manner. The results suggest that PACAP 27, PACAP 38, and LHRH stimulate the release of $\mathrm{LH}$ in the cattle by acting directly at anterior pituitary cells.
\end{abstract}

Key words: PACAP, LHRH, LH, Cattle.

(J. Reprod. Dev. 41: 15-20, 1995)

$\mathbf{P}$ ituitary adenylate cyclase-activating polypeptide with 38 residues (PACAP 38 ) and a shorter form of the peptide corresponding to the N-terminal 27 residues (PACAP 27) were recently isolated from the ovine hypothalamus and characterized $[1,2]$. PACAP is localized to nerve fibers in both external and internal zones of the median eminence and the pituitary stalk that are in close contact with the hypophysial portal capillaries [3]. PACAP specific receptors are found in the anterior pituitary cell membrane [4]. The physiological role of PAC-

Accepted for publication: August 18, 1994

Correspondence: S. Kanematsu
$\mathrm{AP}$ in regulating the anterior pituitary gland has not been fully elucidated. As PACAP 27 and PACAP 38 stimulate adenylate cyclase activity in rat pituitary cells $[1,2,5-7]$, it was suggested that the peptides might act as a hypophysiotrophic hormone. PACAP 38 was reported to induce the release of anterior pituitary hormones in rats but the results of the reports were at variance $[1,8,9]$. In a static pituitary cell culture system, PACAP 38 did not increase the release of any pituitary hormone despite considerable intracellular cyclic AMP (cAMP) accumulation in the rat [1]. Other studies demonstrated that PACAP 38 weakly stimulates $\mathrm{LH}$ and FSH release while it has no effect on GH, 
ACTH or TSH release from rat pituitary cells in static culture system $[8,10]$. On the other hand, the in vivo effect of PACAP 38 is also inconsistent. It has recently been reported that infusion of PACAP 38 at a rate of $3.2 \mathrm{pmol} / \mathrm{kg}$ per min has no effect on the release of gonadotrophin in human [11]. In contrast, it has been demonstrated that either intracerebroventricular or intraatrial injection of PACAP 38 stimulated the release of $\mathrm{LH}$ in male rats [9]. However, there are no reports concerning the physiological role of PACAP in LH release in ruminant animals. The effect of PACAP 27 on the release of $\mathrm{LH}$ remains to be investigated. Therefore, in the present study, we attempted to determine the direct effects of PACAP 27 and PACAP 38 on the LH release from cultured bovine anterior pituitary cells.

\section{Materials and Methods}

\section{Peptides}

PACAP 27 was synthesized by Dr. Shinichi Ohashi of National Institute of Bioscience and Human Technology, Tsukuba, Japan. PACAP 38 and LHRH were obtained from the Peptide Institute Inc. (Osaka, Japan).

\section{Bovine pituitary cell dispersion}

Pituitary glands were removed from eleven Holstein steers aged 17-18 months at a local slaughterhouse within $1 \mathrm{~h}$ after death, and were brought to our laboratory within $1 \mathrm{~h}$ in ice cold Krebs-Ringer bicarbonate buffer to which was added $1.8 \mathrm{mg} / \mathrm{ml}$ glucose, $0.5 \mathrm{mg} / \mathrm{ml}$ bacitracin (Wako Pure Chemical Industries LTD., Osaka, Japan), 1.0 $\mathrm{mg} / \mathrm{ml}$ bovine serum albumin (BSA; Boehringer Mannheim, Germany), $0.1 \mathrm{mg} / \mathrm{ml}$ streptomycin, and $100 \mathrm{IU} / \mathrm{ml}$ penicillin (modified KRB buffer). The pituitary glands were cut sagittally into halves before immersion into the buffer.

Anterior pituitary (AP) tissues were diced into approximately $1 \mathrm{~mm}^{3}$ cubes and then placed into a dish with the buffer. The mean wet weights and standard errors of AP tissues in 11 steers were 1.37 $\pm 0.08 \mathrm{~g}$. The AP tissues were immediately used for primary cell culture according to a modification of the procedure of Vale et al. [12]. The AP tissues were rinsed 4 times with HEPES buffer [NaCl, $137 \mathrm{mM} ; \mathrm{KCl}, 5 \mathrm{mM} ; \mathrm{Na}_{2} \mathrm{HPO}_{4} \cdot 2 \mathrm{H}_{2} \mathrm{O}, 0.7$ $\mathrm{mM}$; N-2-hydroxyethylpiperazine-N'-2-ethane- sulfonic acid (HEPES; GIBCO, Gland Island, NY, USA), $25 \mathrm{mM}$; glucose, $10 \mathrm{mM} ; \mathrm{CaCl}_{2} \cdot 2 \mathrm{H}_{2} \mathrm{O}, 36$ $\mu \mathrm{M}]$, placed into a siliconized, liquid scintillation vial containing $5 \mathrm{ml} \mathrm{0.4 \%} \mathrm{collagenase} \mathrm{(Wako} \mathrm{Pure}$ Chemical Industries LTD.) and 1\% BSA in HEPES buffer, and then incubated in a water bath for 45 min at $37 \mathrm{C}$ with agitation. The fragments were dispersed by pipetting 300 times every 15 min during the incubation. The tissues were then carefully decanted into a glass centrifuge tube and were centrifuged at $450 \times \mathrm{g}$ for $5 \mathrm{~min}$. Approximately $4 \mathrm{ml}$ of the buffer were discarded, and the pituitaries were poured into a scintillation vial containing 5 $\mathrm{ml} 0.25 \%$ pancreatin (pancreatin $4 \times$; GIBCO) in $\mathrm{Ca}^{2+}$-free HEPES buffer, and incubated for $10 \mathrm{~min}$ at $37 \mathrm{C}$ with agitation. After incubation, $5 \mathrm{ml}$ of Dulbecco's modified Eagle medium (DMEM; GIBCO) which was supplemented with $10 \%$ horse serum (GIBCO), 2.5\% new born calf serum (GIBCO), $1 \%$ non-essential amino acids (GIBCO), 100 $\mathrm{IU} / \mathrm{ml}$ penicillin and $50 \mu \mathrm{g} / \mathrm{ml}$ streptomycin was suspended with a Pasteur pipette. The cells were decanted into centrifuge tubes and centrifuged at $450 \times \mathrm{g}$ for $5 \mathrm{~min}$. Approximately $4 \mathrm{ml}$ of the buffer were discarded, $5 \mathrm{ml}$ fresh DMEM were added, and then the cells were dispersed by gently drawing the fragments into and expelling them out of a Pasteur pipette. This washing procedure was repeated 4 times.

\section{Cell culture}

After centrifugation, the media were discarded and the pelleted cells were resuspended in DMEM $(10 \mathrm{ml})$ with a Pasteur pipette. The dispersed cells were then stained with trypan blue, and the nonstained viable cells were counted with a hemocytometer. Approximately $9 \times 10^{6}$ cells were obtained from a pituitary gland. The cell suspension was randomly plated in 24-well dishes (CORNING; Houston, TX) at a density of $5 \times 10^{4}$ cells per $\mathrm{ml}$ per well. The plated cells were maintained in the DMEM in a humidified atmosphere of $5 \% \mathrm{CO}_{2}$ at $37 \mathrm{C}$ for $72 \mathrm{~h}$.

After incubating for 3 days, the cells were washed 2 times with modified KRB to remove the medium and floating cells. Following washing, the media were replaced with fresh modified KRB buffer containing each dose of the test substance. After $2 \mathrm{~h}$ at $37 \mathrm{C}$, media $(0.9 \mathrm{ml}$ each) were collected for the LH assay. The medium was stored at $-20 \mathrm{C}$ until assayed for the hormone concentrations. 


\section{$L H$ radioimmunoassay ( $R I A)$}

Measurement of bovine LH was performed in duplicate by a double antibody RIA as described previously [13]. The LH standard preparation and hormone for iodination were NIH-LH-B8 and LER1056-C2, respectively. The hormones for the standard and iodination were supplied by Dr. L. E. Reichert Jr. (the Albany Medical College of Union University, Albany, NY, USA). An antiserum against LH (NIH-LH-S18) was generated in guinea pigs in our laboratory, and the crossreaction with other hormones and parallelism was determined as described in a previous report [14]. Goat anti-guinea pig IgG serum (2nd antibody) was supplied by Dr. K. Wakabayashi of the Institute of Endocrinology, Gunma University, Japan. The minimum detectable value of LH was $1.4 \mathrm{ng} / \mathrm{ml}$. In this assay, the intra- and inter-assay coefficients of variation were $2.8 \%$ and $3.9 \%$, respectively.

\section{Statistical analysis}

In each experiment with $10^{-14}$ to $10^{-7} \mathrm{M}$ peptides, five to nine wells were used, and they were repeated two times. For an additional experiment, six to eight wells were used in each experiment with $10^{-16}$ to $10^{-7} \mathrm{M}$ peptides. In each experiment hormone concentrations in the control wells were averaged and the mean was set as $100 \%$. All other hormone values were expressed as percentages of these $100 \%$ values. The data were expressed as mean \pm SE. Statistical analyses were performed with Student's $t$ test after Bartlett's test for uniformity of the variances [15]. In order to examine the dose dependent response of the peptides to release $\mathrm{LH}$, a linear regression analysis method was also employed [15].

\section{Results}

The effects of different concentrations of PACAP $27\left(10^{-16}\right.$ to $\left.10^{-7} \mathrm{M}\right)$ on the release of $\mathrm{LH}$ from cultured bovine anterior pituitary cells are shown in Fig. 1. PACAP 27 significantly increased the release of $\mathrm{LH}$ at the concentrations as low as $10^{-14}$ $\mathrm{M}(\mathrm{P}<0.01)$ compared with control media. The maximum effect of PACAP 27 on $\mathrm{LH}$ release was observed at $10^{-7} \mathrm{M}(9.74 \pm 0.75 \mathrm{ng} / \mathrm{ml}$ vs. $6.93 \pm$ $0.06 \mathrm{ng} / \mathrm{ml}$ in controls). However, PACAP 27 failed to release $\mathrm{LH}$ at the concentrations lower than
$10^{-15} \mathrm{M}$. Percent increases in $\mathrm{LH}$ at the $10^{-14}, 10^{-13}$, $10^{-12}, 10^{-11}, 10^{-10}, 10^{-9}, 10^{-8}$ and $10^{-7} \mathrm{M}$ PACAP 27 were $27.5,30.6,32.1,35.0,35.6,36.2,38.0$ and $40.5 \%$ of the controls, respectively. As shown in Fig. 1, the $\mathrm{LH}$ responses to PACAP 27 were in a dosedependent manner in a dose range of $10^{-16}$ to $10^{-7}$ $\mathrm{M}(\mathrm{r}=0.86 ; \mathrm{P}<0.01)$.

The effects of the different concentrations of PACAP $38\left(10^{-16}\right.$ to $\left.10^{-7} \mathrm{M}\right)$ on the release of $\mathrm{LH}$ from cultured bovine anterior pituitary cells are shown in Fig. 2. PACAP 38 significantly increased the release of $\mathrm{LH}$ at concentrations as low as $10^{-12}$ $\mathrm{M}(\mathrm{P}<0.05)$. The maximum effect was obtained at $10^{-7} \mathrm{M}(21.31 \pm 2.83 \mathrm{ng} / \mathrm{ml}$ vs. $12.42 \pm 0.24 \mathrm{ng} / \mathrm{ml}$ in controls ). However, PACAP 38 failed to stimulate the release $\mathrm{LH}$ at lower concentrations than $10^{-13} \mathrm{M}$. Percent increases in LH at the $10^{-12}, 10^{-11}$, $10^{-10}, 10^{-9}, 10^{-8}$ and $10^{-7} \mathrm{M}$ PACAP 38 were 23.5 , $42.7,47.9,55.2,56.0$ and $71.6 \%$, compared with control levels, respectively. As shown in Fig. 2, PACAP 38 at concentrations from $10^{-16}$ to $10^{-7} \mathrm{M}$ linearly increased the $\mathrm{LH}$ concentrations in the media $(r=0.97 ; \mathrm{P}<0.001)$.

The effects of the different concentrations of LHRH $\left(10^{-16}\right.$ to $\left.10^{-7} \mathrm{M}\right)$ on the release of $\mathrm{LH}$ from cultured bovine anterior pituitary cells are shown

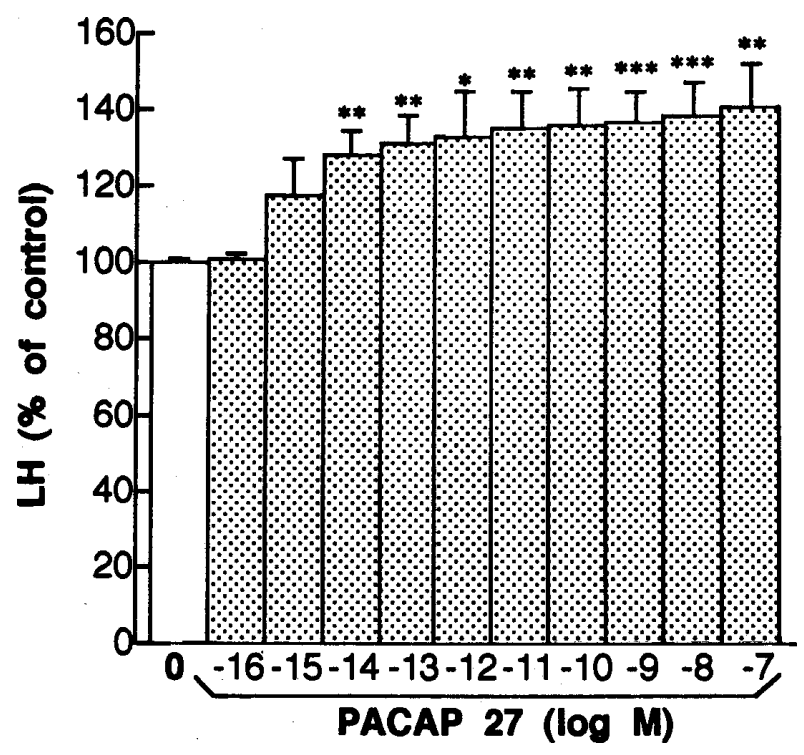

Fig. 1. Effects of PACAP 27 on the release of LH from cultured bovine anterior pituitary cells. Each value represents the mean \pm SE of 8 to 23 determinations. Significant differences from control are indicated by asterisks $\left({ }^{*} \mathrm{P}<0.05,{ }^{* *} \mathrm{P}<0.01,{ }^{* * *} \mathrm{P}<0.001\right)$. 


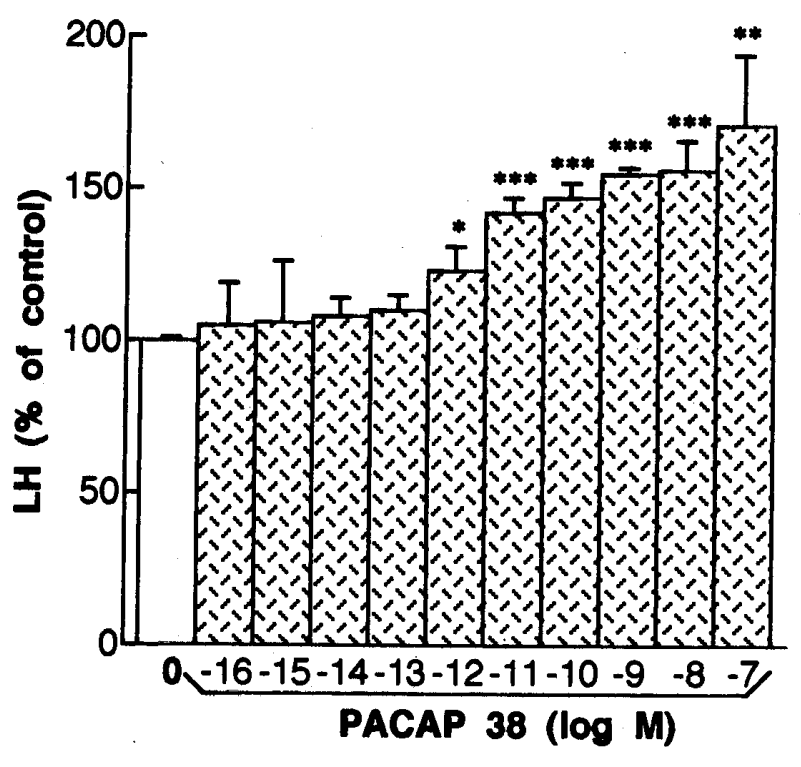

Fig. 2. Effects of PACAP 38 on the release of LH from cultured bovine anterior pituitary cells. Each value represents the mean \pm SE of 6 to 17 determinations. Significant differences from control are indicated by asterisks $\left({ }^{*} \mathrm{P}<0.05,{ }^{* *} \mathrm{P}<0.01,{ }^{* * *} \mathrm{P}<0.001\right)$.

in Fig. 3. LHRH significantly increased the release of $\mathrm{LH}$ at concentrations as low as $10^{-14} \mathrm{M}(\mathrm{P}<0.05)$. The maximum effect of LHRH was obtained at $10^{-7} \mathrm{M}(16.59 \pm 1.32 \mathrm{ng} / \mathrm{ml}$ vs. $4.07 \pm 0.12 \mathrm{ng} / \mathrm{ml}$ in controls). However, LHRH failed to stimulate the release of $\mathrm{LH}$ at lower concentrations than $10^{-15} \mathrm{M}$. Percent increases in $\mathrm{LH}$ at the $10^{-14}, 10^{-13}, 10^{-12}, 10^{-11}$, $10^{-10}, 10^{-9}, 10^{-8}$ and $10^{-7} \mathrm{M}$ LHRH were $14.0,15.8$, $18.6,32.9,44.1,125.7,238.6$ and $307.7 \%$ of the controls, respectively. As shown in Fig. 3, the LH response to LHRH was linear at the dose ranged from $10^{-16}$ to $10^{-7} \mathrm{M}(\mathrm{r}=0.84 ; \mathrm{P}<0.01)$.

The minimal effective concentration of PACAP 27 was $10^{-14} \mathrm{M}$ which was comparable to that of LHRH. In contrast to the stimulating effects of LHRH and PACAP 27 on the release of LH, PACAP 38 failed to stimulate the release of $\mathrm{LH}$ at the concentration of $10^{-14} \mathrm{M}$. Percent increases in LH induced by $10^{-7} \mathrm{M}$ PACAP 27 and $10^{-7} \mathrm{M}$ PACAP 38 were about one tenth and one fifth of that of $10^{-7} \mathrm{M}$ LHRH, respectively.

\section{Discussion}

The present study showed that PACAP 27, PACAP 38 and LHRH stimulated LH release from

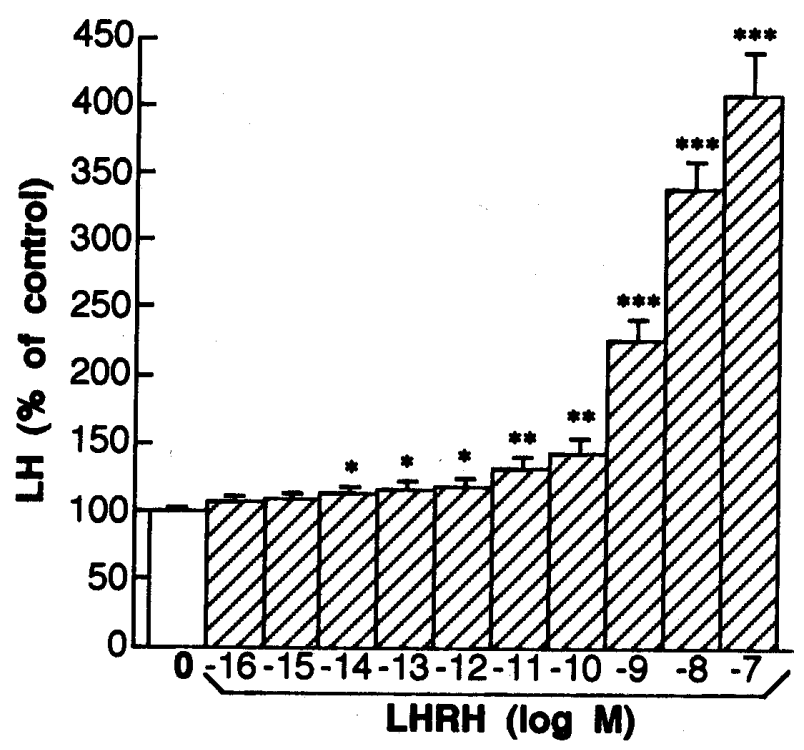

Fig. 3. Effects of LHRH on the release of LH from cultured bovine anterior pituitary cells. Each value represents the mean \pm SE of 7 to 24 determinations. Significant differences from control are indicated by asterisks $\left({ }^{*} \mathrm{P}<0.05,{ }^{* *} \mathrm{P}<0.01,{ }^{* * *} \mathrm{P}<0.001\right)$.

bovine anterior pituitary cells in vitro. These findings may be important for speculating the physiological roles of PACAP 27 and PACAP 38 in ruminant animals.

In the present system with dispersed and cultured bovine anterior pituitary cells, LH release was significantly stimulated by LHRH $\left(10^{-14}\right.$ to $\left.10^{-7} \mathrm{M}\right)$. The minimum effective concentration of LHRH was $10^{-14} \mathrm{M}$, which was much lower than $10^{-11} \mathrm{M}-10^{-9} \mathrm{M}$ reported in other studies using bovine pituitary cell cultures [16-20]. In other animals such as the rat, sheep, and pig, minimum effective concentrations of LHRH to stimulate LH release from anterior pituitary cells were between $10^{-12}$ and $10^{-8} \mathrm{M}[8,12,21-28]$. Therefore, our results indicate that the present system is very sensitive for studying the release of $\mathrm{LH}$ from bovine anterior pituitary cells.

Miyata et al. [1] initially reported that PACAP 38 had no effect on LH secretion in spite of increasing cAMP levels in static cell cultures in rats. PACAP 38 was reported, however, to stimulate the release of LH from cultured rat anterior pituitary cells [8]. In the present study, a dose-dependent increase of $\mathrm{LH}$ secretion was observed in response to PACAP 27 and PACAP 38 in cultured bovine pituitary cells. The present results were in agreement with those 
of Culler and Paschall in rats [8].

On the other hand, the in vivo effect of PACAP 38 was also observed on LH secretion, and the increased LH levels by intraatrial injection of the peptide were much higher than that by intracerebroventricular injection [9]. Therefore, it was suggested that the LH releasing effect of PACAP 38 would be more potent via the anterior pituitary than via the hypothalamus [9]. The results of the present study, in which the PACAP 27 and PACAP 38 induced the release of LH from cultured bovine anterior pituitary cells, agreed with those of Osuga et al. [9] in rats.

Miyata et al. [2] reported that the content of PACAP 27 in ovine hypothalamic tissues appeared to be about one tenth of that of PACAP 38. Furthermore, Arimura et al. [29] reported that the hypothalamus contains the highest concentration of immunoreactive PACAP 38 and PACAP 27 among other tissues in the rat, and that the amount of PACAP 38 is nearly 15 times greater than PACAP 27. In the present study, the minimal effective concentration of PACAP 27 on LH release from cultured bovine anterior pituitary cells was 100 times lower than that of PACAP 38.

Similar distribution of immunoreactive PACAP neurons and fibers was found in the hypothalamus of sheep [3], monkey, and human [30]. Immunoreactive PACAP cell bodies were present in the supraoptic nuclei and the paraventricular nuclei. Immunoreactive nerve fiber networks were also observed throughout the hypothalamus, including both external and internal zones of the tuber cinereum, close to the transition of the pitu- itary stalk (median eminence) [3, 30]. In addition, the fibers run in parallel within the paraventriculo-infundibular tract toward the posterior pituitary, and a dense network of PACAP fibers was observed in both the internal and external zones of the tuber cinereum in the brain of human and monkey [30]. PACAP 38 content in the posterior pituitary was comparable to that of extrahypothalamic areas in the brain, while the anterior pituitary contained only a small amount of the peptide [29]. Specific high affinity binding sites for PACAP 27 and 38 were observed in rat pituitary cell membrane [4]. PACAP may be released either in the long hypopysial portal vessels or the short portal vessels from the posterior pituitary acting on the adenohypophysis [31].

In conclusion, our results suggest that PACAP 27 and PACAP 38 stimulate LH release in cattle via a direct action on anterior pituitary cells.

\section{Acknowledgments}

The authors wish to thank Prof. K. Wakabayashi, the Institute of Endocrinogy, Gunma University, Japan for providing goat anti-guinea pig IgG serum to sLH. The authors are indebted to Dr. L. E. Reichert Jr., the Albany Medical College of Union University, USA for LER-1056-C2 and NIH-LH-B8. Appreciation is also expressed to the Iwate Livestock-Products Distribution Center (Ltd.) for pituitary glands of the cattle. Finally, we thank Dr. Paul Langman of Iwate Medical University for assistance with English usage.

\section{References}

1. Miyata A, Arimura A, Dahl RR, Minamino N, Uehara A, Jiang L, Culler MD, Coy DH. Isolation of a novel 38 residue-hypothalamic polypeptide which stimulates adenylate cyclase in pituitary cells. Biochem Biophys Res Commun 1989; 164: 567574.

2. Miyata A, Jiang L, Dahl RD, Kitada C, Kubo K, Fujino M, Minamino N, Arimura A. Isolation of a neuropeptide corresponding to the N-terminal 27 residues of the pituitary adenylate cyclase activating polypeptide with 38 residues (PACAP38). Biochem Biophys Res Commun 1990; 170: 643-648.

3. Köves K, Arimura A, Somogyvári-Vigh A, Vigh $\mathrm{S}$, Miller J. Immunohistochemical demonstration of a novel hypothalamic peptide, pituitary adenylate cyclase-activating polypeptide, in the ovine hypothalamus. Endocrinology 1990; 127: 264-271.

4. Gottschall PE, Tatsuno I, Miyata A, Arimura A. Characterization and distribution of binding sites for the hypothalamic peptide, pituitary adenylate cyclase-activating polypeptide. Endocrinology 1990; 127: 272-277.

5. Isobe K, Nakai T, Takuwa Y. $\mathrm{Ca}^{2+}$-dependent stimulatory effect of pituitary adenylate cyclase-activating polypeptide on catecholamine secretion from cultured porcine adrenal medullary chromaffin cells. Endocrinology 1993; 132: 1757-1765.

6. Schomerus E, Poch A, Bunting R, Mason WT, 
McArdle CA. Effects of pituitary adenylate cyclase-activating polypeptide in the pituitary: activation of two signal transduction pathways in the gonadotrope-derived $\alpha$ T3-1 cell line. Endocrinology 1994; 134: 315-323.

7. Tatsuno I, Somogyvári-Vigh A, Mizuno K, Gottschall PE, Hidaka H, Arimura A. Neuropeptide regulation of interleukin-6 production from the pituitary: stimulation by pituitary adenylate cyclase activating polypeptide and calcitonin generelated peptide. Endocrinology 1991; 129: 1797-1804.

8. Culler MD, Paschall CS. Pituitary adenylate cyclase- activating polypeptide (PACAP) potentiates the gonadotropin- releasing activity of luteinizing hormone-releasing hormone. Endocrinology 1991; 129: 2260-2262.

9. Osuga Y, Mitsuhashi N, Mizuno M. In vivo effect of pitutary adenylate cyclase activating polypeptide 38 (PACAP 38) on the secretion of luteinizing hormone (LH) in male rats. Endocrinol Japon 1992; 39: 153-156.

10. Jarry H, Leonhardt S, Schmidt WE, Creutzfeldt W, Wuttke W. Contrasting effects of pituitary adenylate cyclase activating polypeptide (PACAP) on in vivo and in vitro prolactin and growth hormone release in male rats. Life Sci 1992; 51: 823-830.

11. Hammond PJ, Talbot $K$, Chapman R, Ghatei MA, Bloom SR. Vasoactive intestinal peptide, but not pituitary adenylate cyclase-activating peptide, modulates the responsiveness of the gonadotroph to LHRH in man. J Endocrinol 1993; 137: 529-532.

12. Vale W, Grant G, Amoss M, Blackwell R, Guillemin R. Culture of enzymatically dispersed anterior pituitary cells: functional validation of a method. Endocrinology 1972; 91: 562-572.

13. Scaramuzzi RJ, Blake CA, Papkoff $\mathbf{H}$, Hilliard J, Sawyer CH. Radioimmunoassay of rabbit luteinizing hormone: serum levels during various reproductive states. Endocrinology 1972; 90: 1285-1291.

14. Kanematsu S, Sato N, Hashizume T. Effects of cholecystokinin on luteinizing hormone release from perifused hypothalamus-pituitary in the castrated bulls. Jpn J Anim Reprod 1990; 36: 54-59.

15. Wakabayashi K. Arrangement of Experimental Data (PC- 8801, 9801). Tokyo: Baihukan; 1984 (In Japanese).

16. Padmanabhan V, Kesner JS, Convey EM. Effects of estradiol on basal and luteinizing hormone releasing hormone (LHRH)-induced release of luteinizing hormone ( $\mathrm{LH}$ ) from bovine pituitary cells in culture. Biol Reprod 1978; 18: 608-613.

17. Chao CC, Scribner KA, Dixon JE, Malven PV. Failure of neuropeptide $\mathrm{Y}$ to modulate the release of LH and prolactin by cultured bovine pituitary cells. Domest Anim Endocrinol 1987; 4: 309-314.

18. Chao CC, Moss GE, Malven PV. LH release from dispersed bovine pituitary cells in culture: in vitro effects of estradiol and procedural variables.
Domest Anim Endocrinol 1987; 4: 139-147.

19. Moss GE, Parfet JR, Marvin CA, Allrich RD, Diekman MA. Pituitary concentrations of gonadotropins and receptors for GnRH in suckled beef cows at various intervals after calving. J Anim Sci 1985; 60: 285-293.

20. Chao CC, Moss GE, Malven PV. Direct opioid regulation of pituitary release of bovine luteinizing hormone. Life Sci 1986; 39: 527-534.

21. Adams TE, Wagner TOF, Sawyer HR, Nett TM. $\mathrm{GnRH}$ interaction with anterior pituitary. II. Cyclic AMP as intracellular mediator in the GnRH activated gonadotroph. Biol Reprod 1979; 21: 735-747.

22. Huang ES-R, Miller WL. Effects of estradiol- $17_{\beta}$ on basal and luteinizing hormone releasing hormone-induced secretion of luteinizing hormone and follicle stimulating hormone by ovine pituitary cell culture. Biol Reprod 1980; 23: 124-134.

23. Walker AM, Hopkins CR. Dissociation of the porcine anterior pituitary: the kinetics of luteinizing hormone release in response to luteinizing hormone-releasing hormone. Mol Cell Endocrinol 1978; 12: 177-187.

24. Vale W, Grant G. In vitro pituitary hormone secretion assay for hypophysiotropic substances. Methods in Endocrinology 1975; 37: 82-93.

25. Nakano H, Fawcett CP, McCann SM. Enzymatic dissociation and short-term culture of isolated rat anterior pituitary cells for studies on the control of hormone secretion. Endocrinology 1976; 98: 278288.

26. Drouin J, Lagasé L, Labrie F. Estradiol-indused increase of the $\mathrm{LH}$ responsiveness to $\mathrm{LH}$ releasing hormone (LHRH) in rat anterior pituitary. Endocrinology 1976; 99: 1477-1481.

27. Tang LKL, Spies HG. Effects of gonadal steroids on the basal and LRF-induced gonadotropin secretion by cultures of rat pituitary. Endocrinology 1975; 96: 349-356.

28. Drouin J, Labrie F. Selective effect of androgens on $\mathrm{LH}$ and FSH release in anterior pituitary cells in culture. Endocrinology 1976; 98: 1528-1534.

29. Arimura A, Somogyvári-Vigh A, Miyata A, Mizuno K, Coy DH, Kitada C. Tissue distribution of PACAP as determined by RIA: highly abundant in the rat brain and testes. Endocrinology 1991; 129: 2787-2789.

30. Vigh S, Arimura A, Köves K, Somogyvári-Vigh A, Sittion J, Fermin CD. Immunohistochemical localization of the neuropeptide, pituitary adenylate cyclase activating polypeptide (PACAP), in human and primate hypothalamus. Peptides 1991; 12: 313-318.

31. Porter JC, Kamberi IA, Grazia YR. Pituitary blood flow and portal vessels. In: Martini L, Ganong WF (eds.), Frontiers in Neuroendocrinology. New York: Oxford University Press; 1971: 145-175. 